\title{
Review of methods and indicators in sustainable urban transport studies overview from 2000 to 2016
}

\author{
Puji Adiatna Nadi*, AbdulKader Murad \\ Department of Urban and Regional Planning, Faculty of Environmental Design, King Abdulaziz University \\ Jeddah, 21589, Saudi Arabia
}

Article history:

Received: 2 October 2017 / Received in revised form: 26 November 2017 / Accepted: 30 November 2017

\begin{abstract}
The attention of countries either the developed or developing countries on sustainable urban transport is becoming more popular. The purpose of paper is to review the methods and the indicators used for measuring performance of sustainable urban transport. This study is based on the literature review and the case study observation and also uses the quantitative assessment. It reviews the theoretical aspects of sustainability factors at various research works and performance indicator in urban transportation. The indicators were classified into two major categories: (i) assessment methods in sustainable urban transport (SUT), and (ii) basic of sustainability indicators for urban transport. This study found several types of analytical techniques for measuring sustainability indicators in urban transport. It also identify five indicators as basic element to measure sustainable urban transport performance i.e. traffic congestion, traffic air pollution, traffic noise pollution, traffic accidents and land consumption for transport infrastructure.
\end{abstract}

Keywords: sustainable urban transportation; basic indicator; assessment methods.

\section{Introduction}

The essence of transportation activity is a form of traffic movement to change the economic value based on the goods and services. Recently, problems in the transport system occurred at almost all the countries in the world. One of the main paradigms in transportation aspect is through efforts to establish a sustainable form of transportation. By involving the existing transportation readiness and preparation of plans for the future, performance indicators are needed to adjust the concept of sustainability. The rapid urban growth has resulted in constant haphazard urban condition as well as land use and transportation issues, such as urban sprawl and congestion. The high economic activity of the society greatly affects the availability of the reliable urban transport. The concept of sustainable urban transport development is a mandatory requirement.

Trends issues in sustainability and urban transport become most popular in the rapidly city growth, especially developing countries. Because they have huge population in middle income level and excessive number of vehicles ownerships. For instance, the developing countries will need about 25 million kilometres of pave road lane and 335,000 kilometres of rail track majority on 2050 [1]. Therefore, the attention for sustainability in transportation is urgent to be realized. The purpose of this paper is to review the methods and indicators in measuring performance of sustainable urban transport. To

* Corresponding author. Tel.: +966 546783750

Email: padiatna@stu.kau.edu.sa. achieve the purpose of the research objective, it begins improving the research questions; what are the methods and indicators to measure sustainable urban transport performance current practices? Assessment and measurability are crucial for cities with largely complex systems in realising efficient choices [2]. In the measurement of sustainable urban transport performance, it is important to identify methods and indicators as material to be analysed. This paper proposes some work to compile the methods and indicators from previous research, especially in sustainable urban transport studies.

\section{Materials and Methods}

This study is based on the literature review, case study observation and using quantitative assessment. It reviews the theoretical aspects of research work of sustainability factors and performance in urban transportation. The reason of undertaking methods is to establish the depth and breadth of the current state of sustainability knowledge in area of transportation system, particularly in urban transport.

Survey is based on international journal studies, include thesis, e-books, and conference proceeding papers. The study selects the topics through electronic search engine. During exploration, the authors used some key words or terms: indicators, sustainable urban transport, and performance. The first term is applied in order to generate all studies that treat the relationship theme between urban transportation system and sustainability development concepts, including papers referring to this subject in different techniques and methods used. The second term purposes to find all studies title related 
with sustainable urban transport (SUT); this attempt to delimit papers related in transportation sector. Finally, the last term are adopted to generate more precise in search result about how to measure the performance of sustainable urban transport thorough some indicators.

The electronics sources that authors used are Science Direct, Springer Link, JSTOR (Journal Storage), and Scholar Google. Also, the authors examine some references cited in each relevant literature source to obtain additional sources of knowledge. The research covers a period of more than ten years between 2000 and 2016. This paper found 59 studies were published from Asia, Africa, Europe, Australia and America to collect variables regarding sustainable urban transport. The studies investigate the relationship between urban transport and sustainability indicators. Next step, authors exclude all papers that are not related to indicators of sustainable and urban transport sector, through identification on the title of journals, abstract and introduction section. As the result, the papers with only specific in indicators measurement and sustainable urban transport are analyzed in this study.

In this stage, the authors used literature review and research in the field sustainable urban transport. This study will focus on sustainable urban transport. The studies will be classified into five major categories: (i) based on year and number of articles, (ii) based on scientific institutions-country case studies, (iii) based on types of studies, (iv) based on methods of studies, and (v) based on indicators used in studies. For the sustainability knowledge especially how to measure its performance, the authors have filtered the papers in assessment methods of the studies. Selection of some indicators was also used in sustainable urban transport to measure its performance. According this section, the papers will explain about sustainability indicators that influence toward urban transport performance.

\section{Results and Discussion}

The authors search several journals about SUT in search engine and get a lot of useful information. These are categorized in seven figures and two tables to show several specific results and thus to reveal certain necessary and equally linked aspects of sustainable urban transport, indicators, and performance. The numbers of studies on sustainable urban transport demonstrate huge information in research methods types and indicators used. The use of the complex methodology of analysis in SUT studies reflected in the abstracts of the publications. The use of SUT indicators in each study requires a deeper exploration into the contents.

The results of search revealed 59 studies that specifically deal with SUT. There was no research found in 2000-2001, started from 2002 the authors found four studies about SUT. Thereafter, the number of studies found are ups and down in subsequent years. Finally, the overall trend reaches the highest number of studies in 2016 by eight studies. The trends of SUT research generally increase during $2000-2016$ as shown in Fig.1.

The searching process presents several countries as representation of five continents, which are Asia, Australia, Africa, Europe and America. Compared to global area studies
(21 studies), Asia and Europe have the highest number of studies amongst other countries by following five and seven studies, respectively. The area in Germany and Sweden published three papers. Two papers are found in the area of Australia, Pakistan, Malaysia, China, and the UK. The overall distribution of papers based on study area regarding the sustainable urban transport can be seen in Fig.2.

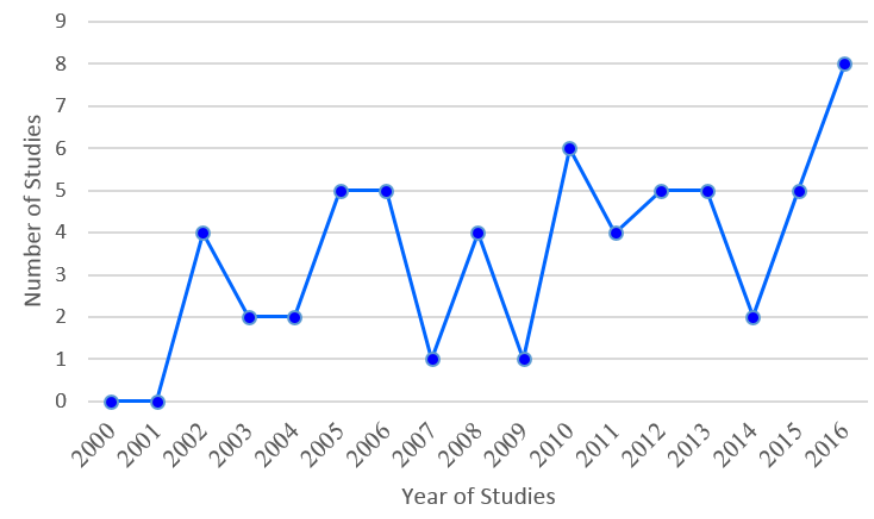

Fig. 1. Number of studies based on Year of Publication in Sustainable Urban Transport studies

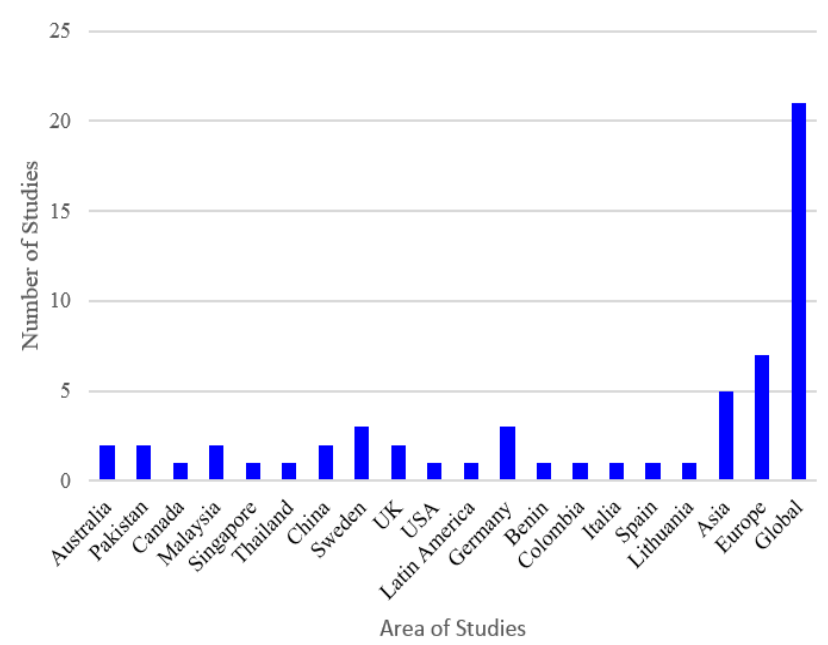

Fig. 2. Number of Studies based on Study Area of SUT

Based on the database of search engine, studies related to sustainable urban transport was also conducted within the period 2000 to 2016 as shown in Fig. 3. The results show that Google Scholar provides the highest results of 25 studies, followed by Science Direct of 19 studies. The Springer Link resulted in five papers, whereas the JSTOR did not find any studies related to the SUT. This finding shows the level of success of the study search engine in providing services to the desired study. It also shows how far the ability of each researcher to contribute in improving the dissemination of knowledge, especially through the media publisher.

The searching process was also conducted based on the discovery of several types of studies related to the SUT as shown in Fig. 4. The highest literatures in the type of a journal had been found about 38 papers. Furthermore, the form of reports, theses and book section were obtained to be five documents. The forms of paper work and conference papers were also available with three studies. 


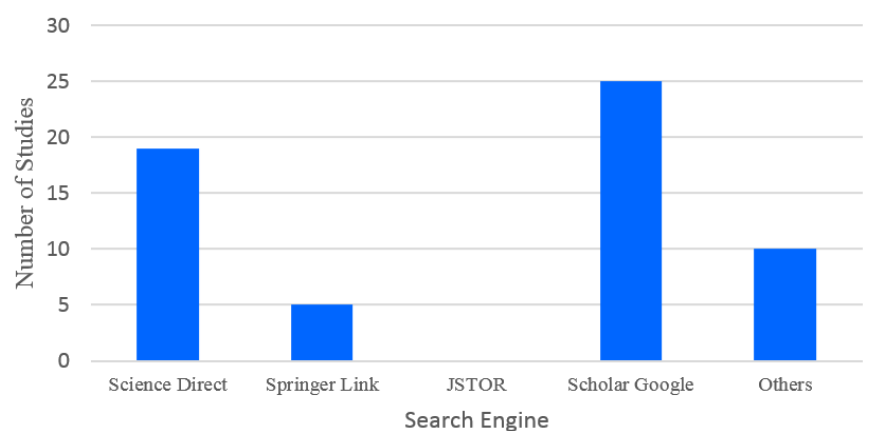

Fig. 3. Number of Studies based on study search engine with SUT topic

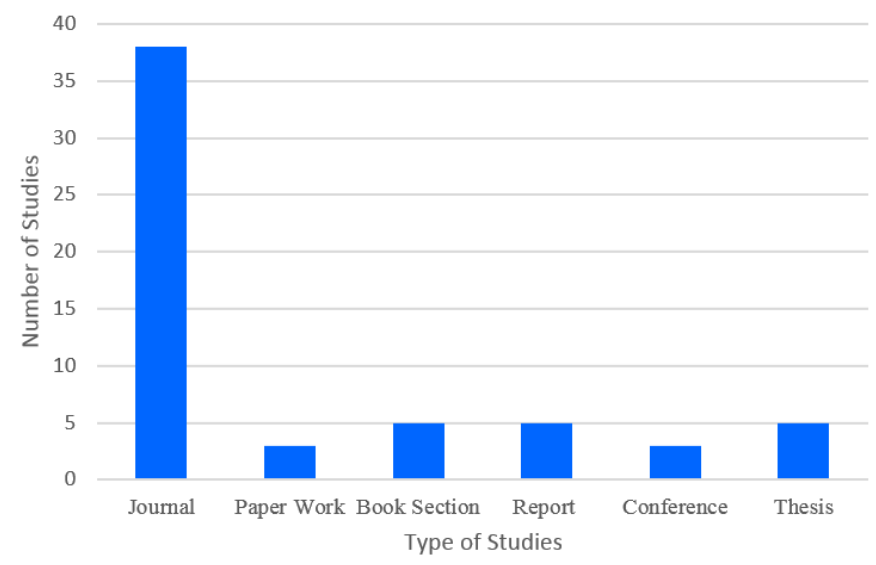

Fig. 4. Type of studies results based on study search engine using SUT topic

Based on the criteria of journal titles, some choices of the researchers to publish their research can be conducted as shown in Table 1. It was found about 8 titles journal chosen by most researchers in the topic of the SUT. Transport Research Procedia and Transport Policy are observed as the most chosen by the researchers. Those are then followed by the others: Habitat International, Research in Transportation Economics, The Journal of Urban Planning and Development, Transportation Research Board, European Journal of Transport and Infrastructure Research (EJTIR) and Procedia Social and Behavioral Sciences.

These findings interpreted a global overview of studies relating to sustainable urban transport. Research on the theme of SUT continued to increase. This means an increasing attention from researchers to explore SUT studies in many disciplinary. Research on the SUT can be based on one or more disciplinary science. The three pillars of sustainability, namely social, economic and environmental, it hinted that the SUT inherently have correlation of the various aspects of interdisciplinary. There are indicators that serve as a tool to assess the extent to which performance of the SUT. There are some other findings are more in depth are described in the following section.

\subsection{Methods of studies in Sustainable Urban Transport}

The methods used in previous studies include:

\section{a. Literature Review}

This method has several research objectives such as: to discuss the definition of SUT, land use and the counter indicator and classification of Sustainable Urban Transport based on the geographical scale [3], describes the nature and targets of the SUT [4], estimates of the future situation of SUT, criticism and its components [5], transfer policy and its influence on the SUT [6], depictions of SUT in developing countries [7], analysis of indicators and variables of SUT [2], discusses the advantages and disadvantages of a transportation planning related to the concept of sustainability [8] and evaluate the existing transport policies and develop strategies related SUT [9].

Table 1. Journal titles, total citations and average annual number of citations of 8 most in the SUT studies

\begin{tabular}{lccc}
\hline Journals Title & $\begin{array}{c}\text { Paper } \\
\text { numbers }\end{array}$ & $\begin{array}{c}\text { Total } \\
\text { Citations* }\end{array}$ & $\begin{array}{c}\text { Average } \\
\text { Citations } \\
\text { per year* }\end{array}$ \\
\hline $\begin{array}{l}\text { Transportation Research } \\
\text { Procedia }\end{array}$ & 4 & 1768 & 4.46 \\
Transport Policy & 4 & 1341 & 2.39 \\
Habitat International & 2 & 802 & 2.41 \\
$\begin{array}{l}\text { Research in Transportation } \\
\text { Economics }\end{array}$ & 2 & 245 & 1.04 \\
$\begin{array}{l}\text { Journal Urban Planning and } \\
\text { Development }\end{array}$ & 2 & 218 & 1.48 \\
$\begin{array}{l}\text { Procedia - Social and } \\
\text { Behavioral Sciences }\end{array}$ & 2 & 159 & 0 \\
$\begin{array}{l}\text { European Journal of } \\
\text { Transport and Infrastructure }\end{array}$ & & & 1.06 \\
Research (EJTIR) & & 58 & \\
Transportation Research & 2 & & \\
Board & & & \\
\hline
\end{tabular}

Source: www.scimagojr.com

\section{b. Framework Analysis}

This method is used by researchers to discuss the formulation of transportation policy which aims at realizing SUT program through analysis framework [10];[11], [12] and investigate the application of the SUT from its institutional system and explain the factors that cause incompatibility [13].

\section{c. Decision support tools}

It is used to predict the future performance of the sustainable urban transport [14].

\section{d. Balanced Score Card (BSC)}

The analytical framework is created using this method to assess performance of the SUT [15].

\section{e. Discussion}

The model is applied in a discussion with the objective to define and connote of SUT [16], policy issues [17] [18], energy consumption in transport [19], differences in performance measurement of SUT [20] and related tools that can be used to create a more friendly urban movement [21].

\section{f. Description}

Many studies use this method for explaining the research in theme of sustainable urban transport. Some of the studies using this method are as follows: to describe the trends, problems and implementation of SUT [22]-[24], 
transportation effect on urban pollution and climate change [25], the development of an initial supplies of sustainable transportation performance indicators [26], concepts, policies and methodologies of SUT [27]-[32], use of technology [33], comparative studies in cities in a common strategy of SUT [34], [35], approaches that unites stakeholders views on the SUT [36], BRT development to promote the SUT to be more economically, socially and environmentally [37], [38], common environmental barriers and the problem [39], sources of financing [28], [40], [41], interventions in infrastructure and its indicators [42], introduces measuring tool for SUT [43], [44], introduce the use of spatial analysis for the SUT [45] and demonstrate quantitative methods for SUT [46].

\section{g. Backasting Scenario Approach}

This method is used to formulate a wider perspective of the future prospects and policy options to achieve the SUT objectives [47].

\section{h. Policy evaluation}

The investigation of how the transport policy in countries with rapid economic development can be beneficial and profitable and how its relevance to sustainable urban transport system [48].

\section{i. Expenses evaluation}

This method relates to the analysis of wasted time caused by congestion as one of the main factors in the measurement of the SUT [49].

\section{j. Correlation analyses}

This method is used to describe the condition of the cities related to the level of conformity with the SUT system and identify the factors [50], [51] and also identify the relationship between sustainability and indicators policies [52].

\section{k. Dynamic optimization}

It is used to define and explain the requirements of the SUT development based on the methods and tools which used in the analysis of transport planning [53].

\section{l. Vector Calculus}

This method is used to analyze the relationship uniformity between regions that implement sustainable transport system with the concept of sustainable development [54]

\section{m. Questioner}

The proposed method to determine the extent of public opinion on the financing policies of congestion [55], as well as a way to see the results of the implementation of policy and planning in the freight transport in city [56].

\section{n. Modeling}

This method is used to assess the SUT of factors that influence such as wind, roadside buildings, road geometry, traffic conditions, fleet composition, driver behavior [57]. The summary assessment methods of SUT are presented in Table 2.

Fig. 5 describes a number of studies with its research methods. It was found about 14 types of methods used by previous researchers on the SUT theme. The description method was widely used by 27 studies. It was then followed by a literature review methods with nine studies and discussion method with six studies.

Table 2. GIS Assessment methods in SUT studies

\begin{tabular}{|c|c|c|}
\hline Methods & Objectives & Authors \\
\hline \multirow[t]{8}{*}{$\begin{array}{l}\text { Literature } \\
\text { Review }\end{array}$} & $\begin{array}{l}\text { The literature review on urban } \\
\text { sustainable transportation, to classify it } \\
\text { by geographical scale, To explore the } \\
\text { definition of SUT and land use and these } \\
\text { indicators for measure it. }\end{array}$ & [3] \\
\hline & $\begin{array}{l}\text { - A review of the current setting and } \\
\text { targets for sustainable urban transport. }\end{array}$ & [4] \\
\hline & $\begin{array}{l}\text { The literature review of moving forward } \\
\text { of SUT and critical of four essential } \\
\text { components. }\end{array}$ & {$[5]$} \\
\hline & $\begin{array}{l}\text { - Reviewed of policy transfer in transport } \\
\text { and its influenced. }\end{array}$ & [6] \\
\hline & $\begin{array}{l}\text { The reviews of sustainable urban } \\
\text { transport in cities in developing } \\
\text { countries. }\end{array}$ & [7] \\
\hline & $\begin{array}{l}\text { - Analyzed the SUT indicators and } \\
\text { collected its variables. }\end{array}$ & {$[2]$} \\
\hline & $\begin{array}{l}\text { - Review the competence transport } \\
\text { planning in correlation with a sustainable } \\
\text { urban transport system in the city. }\end{array}$ & [8] \\
\hline & $\begin{array}{l}\text { Evaluates the existing transport policies } \\
\text { and developed strategies of SUT. }\end{array}$ & [9] \\
\hline \multirow[t]{4}{*}{$\begin{array}{l}\text { Framework } \\
\text { Analysis }\end{array}$} & $\begin{array}{l}\text { - Propose analytic framework for transport } \\
\text { policy making. }\end{array}$ & {$[10]$} \\
\hline & $\begin{array}{l}\text { - Propose theoretical framework of } \\
\text { transport sustainability development } \\
\text { - }\end{array}$ & [11] \\
\hline & $\begin{array}{l}\text { - Develops a framework of sustainability } \\
\text { of urban transportation } \\
\text { - Proposed a framework and a tool to } \\
\text { assess urban transport sustainability. }\end{array}$ & [12] \\
\hline & $\begin{array}{l}\text { Explore the SUT applications from } \\
\text { institutional capacities and explain the } \\
\text { mismatch in urban transport capacity } \\
\text { using the theoretical framework of path } \\
\text { dependence. }\end{array}$ & [13] \\
\hline $\begin{array}{l}\text { Decision } \\
\text { support } \\
\text { tools }\end{array}$ & $\begin{array}{l}\text { - Studies of decision support tools to } \\
\text { predict the future performances of SUT }\end{array}$ & [14] \\
\hline $\begin{array}{l}\text { Balanced } \\
\text { Score Card } \\
\text { (BSC) } \\
\end{array}$ & $\begin{array}{l}\text { - Develop framework for SUT } \\
\text { performance using Balanced Score Card } \\
\text { (BSC) }\end{array}$ & {$[15]$} \\
\hline \multirow[t]{5}{*}{ Discussion } & $\begin{array}{l}\text { - Discussion in SUT policies on Asian } \\
\text { cities }\end{array}$ & [17] \\
\hline & $\begin{array}{l}\text { - Discussed about energy consumption in } \\
\text { transportation } \\
\text { - Discussed of different measure of SUT }\end{array}$ & [19] \\
\hline & $\begin{array}{l}\text { - Examines some policies about SUT and } \\
\text { identifies promising ideas }\end{array}$ & [20] \\
\hline & $\begin{array}{l}\text { - Discussed about definition and } \\
\text { connotation of SUT }\end{array}$ & [18] \\
\hline & $\begin{array}{l}\text { - Discussed six possible tools for making } \\
\text { urban mobility more environmental } \\
\text { friendly }\end{array}$ & $\begin{array}{l}{[16]} \\
{[21]}\end{array}$ \\
\hline \multirow[t]{5}{*}{ Description } & $\begin{array}{l}\text { - Describe the impact of transport on } \\
\text { urban pollution and climate change }\end{array}$ & {$[25]$} \\
\hline & $\begin{array}{l}\text { - Reports on the development of an initial } \\
\text { set of Sustainable Transportation } \\
\text { Performance Indicators (STPI) }\end{array}$ & [26] \\
\hline & $\begin{array}{l}\text { - Described of trends, problems and policy } \\
\text { practices of SUT in Asia EST. }\end{array}$ & [22] \\
\hline & $\begin{array}{l}\text { - Demonstrate that an approach that } \\
\text { integrates the viewpoints of stakeholders } \\
\text { about sustainable urban transport. }\end{array}$ & [36] \\
\hline & $\begin{array}{l}\text { Description about BRT development to } \\
\text { promote SUT to be more economically, }\end{array}$ & {$[37]$} \\
\hline
\end{tabular}




\begin{tabular}{|c|c|}
\hline socially and environmentally. & \\
\hline $\begin{array}{l}\text { - Describe the concepts, policies and } \\
\text { methodologies of SUT. }\end{array}$ & {$[27]$} \\
\hline $\begin{array}{l}\text { Describe the technologies to minimizing } \\
\text { of transport problems in European. }\end{array}$ & [33] \\
\hline $\begin{array}{l}\text { - Describe of comparison study in generic } \\
\text { SUT strategic in three cities. }\end{array}$ & [34] \\
\hline $\begin{array}{l}\text { - Describe a number of common } \\
\text { environmental challenges in SUT and } \\
\text { problems faced by most European } \\
\text { conurbations. }\end{array}$ & [39] \\
\hline $\begin{array}{l}\text { Describes the international background } \\
\text { of SUT using a set of decision-support } \\
\text { tools, the objectives, structure and } \\
\text { interaction with local authorities. }\end{array}$ & [58] \\
\hline $\begin{array}{l}\text { Describe the use of decision-support for } \\
\text { sustainable urban transport strategies. }\end{array}$ & {$[59]$} \\
\hline $\begin{array}{l}\text { Describe the concept of SUT plans and } \\
\text { its analysis in Europe case study. }\end{array}$ & [28] \\
\hline $\begin{array}{l}\text { - To list out of some resources of } \\
\text { financing in SUT }\end{array}$ & {$[42]$} \\
\hline $\begin{array}{l}\text { Describe the objective of a sustainable } \\
\text { transportation system, policy and } \\
\text { infrastructure interventions through } \\
\text { discussion in these indicators. } \\
\text { - Developed tools for SUT experts. }\end{array}$ & [43] \\
\hline $\begin{array}{l}\text { - Tested of transferability of SUT policies } \\
\text { in developed and developing countries. }\end{array}$ & {$[29]$} \\
\hline $\begin{array}{l}\text { Described the use of GIS in field of SUT } \\
\text { from some studies. }\end{array}$ & {$[45]$} \\
\hline $\begin{array}{l}\text { - Propose the importance of SUT plans in } \\
\text { mobility policy in cities. }\end{array}$ & {$[30]$} \\
\hline $\begin{array}{l}\text { - Describe the concept of SUT plans and } \\
\text { its analysis in Europe case study. }\end{array}$ & {$[31]$} \\
\hline $\begin{array}{l}\text { Describe of Asian experiences dealing } \\
\text { with financing and institutional issues as } \\
\text { they relate to creating a more sustainable } \\
\text { development condition. }\end{array}$ & [40] \\
\hline $\begin{array}{l}\text { Analyses the land use-transport } \\
\text { mechanisms to cause chaotic congestion } \\
\text { in developing and proposes land use- } \\
\text { transport instruments and financing } \\
\text { public transport }\end{array}$ & [41] \\
\hline $\begin{array}{l}\text { - Review the book of Sustainable Urban } \\
\text { Transport in an Asian Context }\end{array}$ & {$[35]$} \\
\hline $\begin{array}{l}\text { - presents of quantitative methods in SUT } \\
\text { Planning }\end{array}$ & [46] \\
\hline $\begin{array}{l}\text { - Describe the SUT planning concepts in } \\
\text { the historic inner city }\end{array}$ & {$[60]$} \\
\hline $\begin{array}{l}\text { Observe the aspects that influenced the } \\
\text { state of the urban transportation system. }\end{array}$ & {$[23]$} \\
\hline $\begin{array}{l}\text { Describe the SUT condition in Latin } \\
\text { America thoroughly multiple dimension, } \\
\text { definition, current condition and best } \\
\text { practices. }\end{array}$ & [24] \\
\hline $\begin{array}{l}\text { - Describe such outcomes, identify reasons } \\
\text { which prevent a wider exploitation of } \\
\text { cleaner buses, provide possible } \\
\text { explanations and suggest } \\
\text { recommendations to develop "green" } \\
\text { awareness among bus stakeholders. }\end{array}$ & {$[38]$} \\
\hline $\begin{array}{l}\text { describe the main features of the Urban } \\
\text { Transport Roadmaps } 2030 \text { policy support } \\
\text { tool }\end{array}$ & [44] \\
\hline $\begin{array}{l}\text { To discover a broader viewpoint of } \\
\text { possible future prospects and policy } \\
\text { options in order to achieve SUT } \\
\text { purposes. }\end{array}$ & [47] \\
\hline $\begin{array}{l}\text { to explore the transport policies in fast } \\
\text { emerging economies countries according } \\
\text { to distribute equitable access to profits } \\
\text { and prospects; }\end{array}$ & [48] \\
\hline
\end{tabular}

\begin{tabular}{|c|c|c|}
\hline $\begin{array}{l}\text { Expenses } \\
\text { evaluation }\end{array}$ & - Analyse time waste due to congestions. & [49] \\
\hline \multirow[t]{3}{*}{$\begin{array}{l}\text { Correlation } \\
\text { analyses }\end{array}$} & $\begin{array}{l}\text { - Describe the level of SUT composite } \\
\text { index in various cities in the world and } \\
\text { identified its factors. }\end{array}$ & {$[50]$} \\
\hline & $\begin{array}{l}\text { - Identified relationships between } \\
\text { sustainability and policy indicators. }\end{array}$ & [52] \\
\hline & $\begin{array}{l}\text { Analyze the implementation process of } \\
\text { SUT and to measure the level of } \\
\text { implementations. }\end{array}$ & {$[51]$} \\
\hline $\begin{array}{l}\text { Dynamic } \\
\text { optimizatio } \\
\mathrm{n}\end{array}$ & $\begin{array}{l}\text { To define and describe for SUT } \\
\text { development requirements similar with } \\
\text { methods and tool in analytical transport } \\
\text { planning. }\end{array}$ & {$[53]$} \\
\hline $\begin{array}{l}\text { Vector } \\
\text { Calculus }\end{array}$ & $\begin{array}{l}\text { To analyze relations between the } \\
\text { identified areas of sustainable transport } \\
\text { with the appointment of averages, } \\
\text { standard deviations and variances of the } \\
\text { data. }\end{array}$ & [54] \\
\hline \multirow[t]{2}{*}{ Questioner } & $\begin{array}{l}\text { - Describe the major policy measure of } \\
\text { congestion pricing }\end{array}$ & [55] \\
\hline & $\begin{array}{l}\text { - Presents of study results on the state of } \\
\text { urban freight transport policies and } \\
\text { planning among the local authorities. }\end{array}$ & [56] \\
\hline Modeling & $\begin{array}{l}\text { To modelling the determinant of SUT } \\
\text { (wind, roadside buildings, road } \\
\text { geometry, traffic conditions, fleet } \\
\text { composition, driver behavior). }\end{array}$ & [57] \\
\hline
\end{tabular}

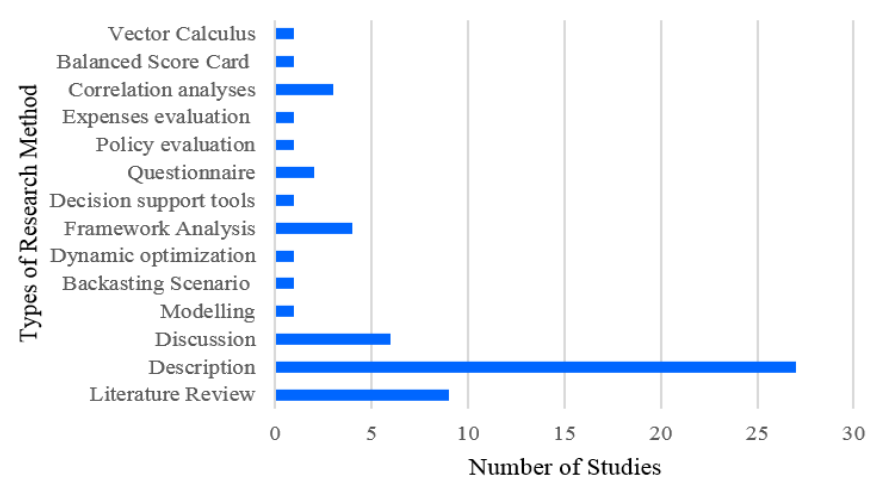

Fig. 5. Research methods type of studies in SUT topic

From the survey between 2000 and 2016, we find the fact that the methods used by the researchers in sustainable urban transport (SUT) studies are mostly qualitative, while it is rare to find research using quantitative methods; this trend is still conducted by researchers in recent years. In fact, the assessment of the performance of an SUT is in the form of indicators i.e., quantitative. Of course, this is an interesting finding to study more in depth through a quantitative approach.

Some quantitative methods can be considered to analyze the performance of sustainable urban transport, such as spatial statistics, spatial mapping, regression analysis, travel preference functions and others. Some methods can take advantage of IT advances such as interactive survey methods using web based and social media and exploring research data through real-time and open data.

\subsection{Indicators for Sustainable Urban Transport Performance}

The essential function of indicators are used for a variety of purposes including measurement, policy formulation, and 
project assessment [61]. Performance measures are measurable criteria that are utilized to evaluate progress towards goals [62]. The others study [63] also suggest that indicators should be used to measure progress, inputs, and outputs of a transport project. According Litman and Burwell [64], the selection of the indicators can greatly influence the analysis results. Therefore, indicators selection process must be considered with comprehensive discussion and analysis. The best practices of indicator selection is performed by following other researcher [65] such as: comprehensive, quality, comparable, understandable, accessible and transparent, cost effective, and net effects. The study by Pojani and Stead [7] proposes a Key Performance Indicators (KPIs) for sustainable urban transport in cities in developing countries i.e. road infrastructure; rail-based public transport; road-based public transport; support for non-motorized travel modes; technological solutions; awareness-raising campaigns; pricing mechanisms; vehicle access restrictions; and control of land-uses. Sustainability indicators for urban transport have two types indicators as numerical indicators and spatial indicators. The numerical indicators resulted from the existing data; while the spatial indicators resulted from GIS analysis [66]. This classification methods are useful to arrange the availability of the data to utilize in indicators analysis.

The performances can be described by indicators in certain concern or the changes over time [2]. This paper also collected special variables regarding sustainable urban transport and to investigate the relationship between urban transport and sustainability indicators. Readiness of indicators as foremost obstacle in the use of sustainability indicators, based on national and regional characteristics [2]. The issues of transportation sustainability need to be improved in many countries regarding the excessive indicators. In scope regional and local objectives, sustainable transportation consists of five indicators i.e. minimizing the air pollution, noise pollution, congestions, accidents and land consumption for transport infrastructure [67]. In the same way, basic concern must be focused to the foremost transportation effects on environment, economy and society i.e.: traffic congestion, air pollution, road safety, noise pollution, and non-renewable resource consumption [11]. Also, the common issues of transportation Asia region is about traffic congestion, traffic accidents and air pollution [68]. The essential issues for the future problems about land consumption by transport infrastructure and noise pollution. Therefore, this study focuses to explore five indicators to measure sustainable urban transport performance based on previous studies. Some of studies used mathematical-statistical methodologies for the selected indictors in reducing the data needed, such as cluster, factor and correlation analyses [2]. The sustainable transportation system have main objectives i.e. reducing travel demand, effective in transport modes, reducing use of resources, energy efficiency and slightly in emission [42]. Table 3 shows the objectives of each indicator in previous studies.

Fig. 6 describes a number of studies to analyze the subject of sustainable urban transport. The studies could represent more than one indicator. In the five basic indicators of the SUT, congestion was used by researchers with 56 studies. It was then followed by air pollution and traffic accident with 54 studies, and transport infrastructure with 43 studies and noise pollution with 43 studies.

Fig. 7 shows the concerns of authors towards main transportation effects on environment, society and economy [11] and the common issues of transportation in Asia region [68] in 5 issues such as: congestion, air pollution, noise pollution, land consumption for transport infrastructure and traffic accident. These previous researchers are focused in the discussion about sustainable urban transport studies. As results, 5 indicators were presented by 28 studies. Four indicators, 3 indicators, 2 indicators and 1 indicator were presented by 17, 9, 4 and 1 studies, respectively. It means that five indicators was mostly used by previous research as basic factor to measure sustainable urban transport performance.

Table 3. Basic indicators in Sustainable Urban Transport (SUT) studies

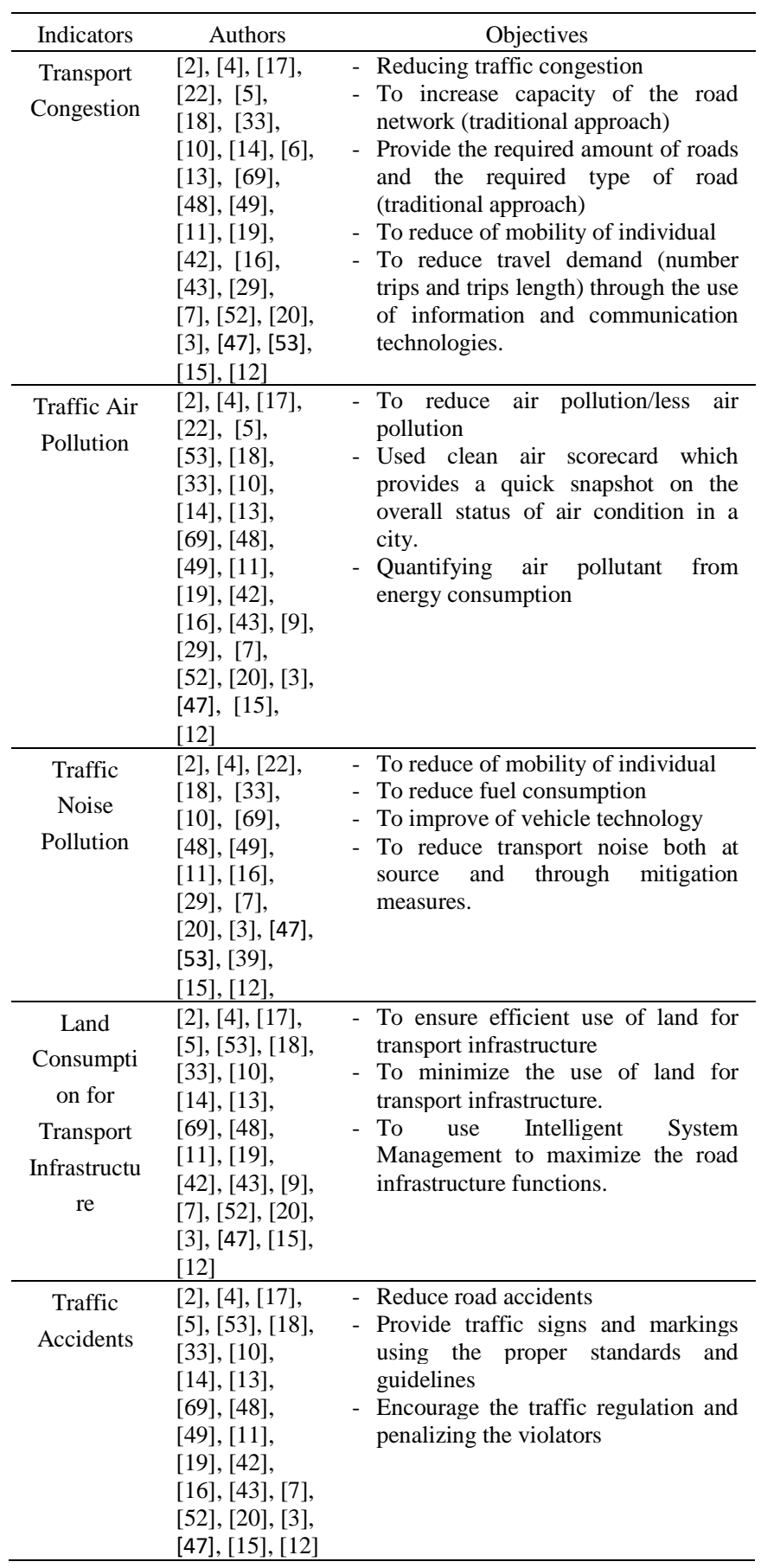




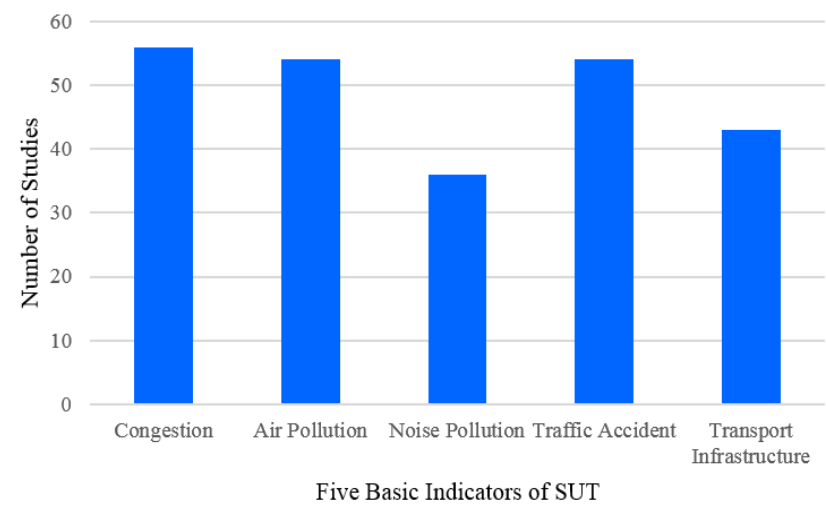

Fig. 6. The use of studies based on five basic indicators on SUT studies

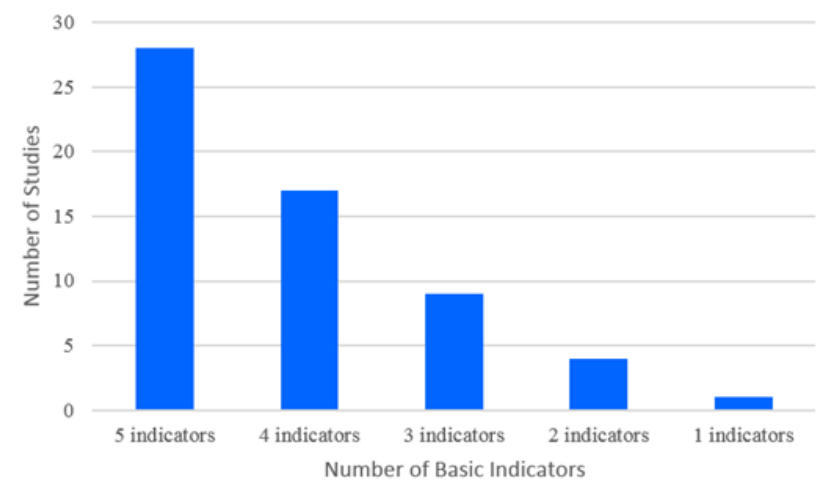

Fig. 7. Number of studies based on utilization of five basic indicators of SUT

Survey conducted in this paper is focused to the paper published between 2000 and 2016 on sustainable urban transport studies. This is a very complex task because each researcher has a different viewpoint and a different focus in assessing the - what sustainable urban transport is-. Also, in identification the type of indicators that can be used as a tool to assess performance. These indicators become too various, according to the perspective of researchers, the condition of the study area and data available. Through the facts which are explained above, the performance assessment of the SUT depends on too many indicators; so it is potentially considered as the weakness, namely the lack of priority in determining indicators. Thus, this study is conducted to find out about the existence of the main indicators from previous studies.

Determination of basic indicators to measure the SUT in the study [11] consists of five main indicators, namely congestion, air pollution, noise pollution, traffic accidents and land consumption for transport infrastructure. Basic indicator as a measurement of performance was indeed indirectly used by most studies of SUT; although there are few studies that only include a part of it. This leading basic indicator can be called as Key Performance Indicators (KPIs). Congestion is a major factor that has most of the studies; because the impact is so high against the transport. The congestion of the indicator could have an impact on other indicators such as air pollution, noise pollution, even the accident and its effect on the increase in the capacity of land-use on transport infrastructure.

These five basic indicators can be reliable enough to be basic standard to assess sustainable urban transportation performance. The application of those indicators are mainly to be applied in developing countries that tend to follow the "negative" trend of developed countries when it experiences bad transportation period in their city before adopting the concept of sustainable transportation. The five basic indicators are expected to identify a region whether it is on a continuous "path" or not, and be able to find out what level of sustainability is.

Based on the facts of previous findings in this study, the research about the SUT is an interesting topic to be further studied. There are some ideas recommended to do the further research. Such as: the study using quantitative research with more specific model, based on findings that dominates in previous research using qualitative approach. Therefore, as one of the main of the quantitative method, spatial analysis is interesting method to be used in analyzing the measurement indicators of the SUT. Also, it is used to explore the indicators as the basis of the SUT (KPIs) in transfers to Spatial Performance Indicators (SPIs). Then, the SPIs could analyze through the approach of Geographic Information Systems (GIS). Similarly, it is important to prepare the availability of data for the assessment indicator of the SUT as one of the main factors is the considerable challenge for researchers. Indicators will work when required data is available and vice versa. In the assessment process of the transportation sustainability in particular city, it can be easily utilized using information technology. Some indicators can already be viewed in real-time, such as traffic congestion, air pollution levels, noise pollution and traffic accidents. Available online data can be integrated with the web-based spatial analysis that is already widely available. In addition to government programs in open data, the statistical data provided can be accessed as the complementary of the existing real-time data. Basic indicators in the future should be explored to minimize the need for this data. Efforts to minimize the size of the values in these five basic indicators of sustainable urban transportation are important in efforts to accelerate human adaptation within existing limitations, or to say 'adaptation in limitation'.

\section{Conclusion}

This paper has presented the methods and the indicators used for measuring performance of sustainable urban transport based on the previous studies. The classification of methods and indicators in SUT studies represent countries with all continents in the world within period 2000 until 2016. It was found that the global case study dominate in SUT theme. Google Scholar provides the highest productive search engine and was also as majority engine in SUT studies. In category of journal name, Transport Research Procedia and Transport Policy are highly chosen by the SUT researchers. This paper also found many types of methods used to measure of sustainability in urban transportation in previous research mostly in qualitative approach. The five basic indicators used to measure sustainable urban transport in previous research are founded i.e. traffic congestion, traffic air pollution, traffic noise pollution, traffic accidents and land consumption for transport infrastructure. The congestion was observed as the indicator most used by SUT researchers. The five basic 
indicators usage is expected to identify a region whether it is on a continuous "path" or not, and be able to find out what level of sustainability is. Also, it is interesting in the future research to explore quantitative methods for SUT with spatial analysis to measure spatial performance indicators using Geographic Information System (GIS).

\section{References}

1 J. Dulac, Global land transport infrastructure requirements. Paris Cedex, 2013

2 A. Buzási and M. Csete, Sustainability indicators in assessing urban transport systems, Period. Polytech. Transp. Eng., vol. 43, no. 3, pp. $138-145,2015$.

3 J. A. Black, A. Paez, and P. A. Suthanaya, Sustainable Urban Transportation: Performance Indicators and Some Analytical Approaches, J. Urban Plan. Dev., vol. 128, no. 4, pp. 184-209, Dec. 2002.

4 P. Hidas and J. Black, Targets and performance indicators for sustainable urban transport: a review of current practice in Sydney, Australia, Sustain. City II, 2002.

5 C. Kennedy, E. Miller, A. Shalaby, H. Maclean, and J. Coleman, The four pillars of sustainable urban transportation, Transp. Rev., vol. 25, no. 4, pp. 393-414, 2005

6 G. Marsden, K. T. Frick, A. D. May, and E. A. Deakin, Good Practice in the Exploitation of Innovative Strategies in Sustainable Urban Transport: City Interview Synthesis, eScholarship, 2009.

7 D. Pojani and D. Stead, Sustainable Urban Transport in the Developing World: Beyond Megacities, Sustainability, vol. 7, no. 6, pp. 7784-7805, 2015.

8 I. Muhammad and L. Nicholas, Promoting Sustainable Urban Transport in Lahore, Pakistan, 2002.

9 F. Gomina Mama, Z. Z. Yang, and D. D. Xia, Strategies for Sustainable Urban Transport: A Case Study of Cotonou, Benin, Int. J. Eng. Res. Africa, vol. 13, pp. 9-20, 2015.

10 M. H. P. Zuidgeest and M. F. A. M. Van Maarseveen, Sustainable urban transport development: A modelling approach, WIT Trans. Ecol Environ., vol. 93, 2006.

11 L. K. Mitropoulos, Sustainability Framework for Urban Transportation Modes and Exploratory Applications, Ph.D. Thesis, University of Hawai'i, 2011.

12 Z. Olofsson, L. Hiselius, and A. Várhelyi, Development of a tool to assess urban transport sustainability: The case of Swedish cities, Int. J. Sustain. Transp., vol. 8318, 2016

13 M. Imran, Sustainable Urban Transport in Pakistan: An Institutional Analysis, Int. Plan. Stud., vol. 15, no. 2, pp. 119-141, 2010.

14 R. D. Jonsson, Analysing Sustainable Urban Transport and Land-Use: Modelling and Land-Use and appraisal frameworks, Ph.D. Thesis, Royal Institute of Technology, 2008.

$15 \mathrm{H}$. Rahman and H. C. Chin, A balanced scorecard for performance evaluation of sustainable urban transport, Int. J. Dev. Sustain., vol. 2, no. 3, pp. 1671-1702, 2013.

16 L. Zhang and Y. Wei, The definition and connotation of the sustainable urban transport, Appl. Mech. Mater., vol. 255, pp. 254-262, 2013.

17 P. Barter, J. R. Kenworthy, and F. Laube, Lessons from Asia on Sustainable Urban Transport, Mak. Urban Transp. Sustain., pp. 252 270, 2003.

18 T. Goldman and R. Gorham, Sustainable urban transport: Four innovative directions, Technol. Soc., vol. 28, no. 1-2, pp. 261-273, 2006.

19 M. Aftabuzzaman and E. Mazloumi, Achieving sustainable urban transport mobility in post peak oil era, Transp. Policy, vol. 18, no. 5, pp 695-702, 2011

20 C. Valdes, A. Monzon, and F. G. Benitez, Sustainable urban transportation strategies: Searching for synergies, KSCE J. Civ. Eng., vol. 20, no. 3, pp. 1066-1075, 2016

21 J. Malasek, A Set of Tools for Making Urban Transport More Sustainable, Transportation Research Procedia, 2016, vol. 14, pp. 876885 .

22 Y. Hayashi, K. Doi, M. Yagishita, and M. Kuwata, Urban Transport Sustainability: Asian Trends, Problems and Policy Practices, EJTIR, vol. 4, no. 1, pp. 27-45, 2004.

23 R. Noriza, R. Ariffin, and R. Khairi, Towards a Sustainable Urban Transport System in the Klang Valley, Malaysia: The key challenges, Procedia - Soc. Behav. Sci., vol. 85, pp. 638-645, 2013.
24 D. Hidalgo and C. Huizenga, Implementation of sustainable urban transport in Latin America, Res. Transp. Econ., vol. 40, no. 1, pp. 6677, 2013.

25 B. Liddle and F. Moavenzadeh, Towards Sustainable Urban Transport: Finding Synergies between Lowering Local and Global Impacts, in Future Cities: Dynamics and Sustainability, F. Moavenzadeh, K. Hanaki, and P. Baccini, Eds. Dordrecht: Springer Netherlands, 2002, pp. 131-147.

26 R. Gilbert et al., Sustainable Transportation Performance Indicators ( STPI ), TRB 2003 Annu. Meet., pp. 1-20, 2003.

27 B. P. Y. Loo and S. Y. Chow, Sustainable Urban Transportation: Concepts, Policies and Methodologies, J. Urban Plan. Dev., vol. 132, no. June, pp. 76-79, 2006

28 R. D. D. Bongardt, Financing Sustainable Urban Transport, 2012.

29 O. Lah et al., Transferability of Sustainable Urban Transport Solutions, in Energy, Climate and Air Quality Challengs: The Role of Urban Trasnport Policies in Developing Countries, 2015.

30 J. Pineda-jaramillo, Sustainability in urban transport plans. Case study: Monorail in a hillside area in Medellín, 2016.

31 Trasporti e Territorio*, Sustainable urban transport plans, Tourism, p. 64, 2010.

32 L. Eboli and G. Mazzulla, Performance indicators for an objective measure of public transport service quality, Eur. Transp., no. 51, pp. 121, 2013.

33 M. Parent, New technologies for sustainable urban transportation in Europe, Transp. Res. Board, no. 1986, pp. 78-80, 2006.

34 H. T. Dimitriou, Towards a generic sustainable urban transport strategy for middle-sized cities in Asia: Lessons from Ningbo, Kanpur and Solo, Habitat Int., vol. 30, no. 4, pp. 1082-1099, 2006.

35 D. Wang, Book review: Sustainable Urban Transport in an Asian Context, J. Transp. Geogr., vol. 24, pp. 539-540, 2012.

36 D. Mohan, Safety and Sustainable Urban Transport, in Urban Transport Development: A Complex Issue, Berlin, Heidelberg: Springer Berlin Heidelberg, 2005, pp. 279-291.

37 L. Liu, Towards Sustainable Urban Transport in China: The Role of Bus Rapid Transit Systems, in Urban Transport Development: A Complex Issue, Berlin, Heidelberg: Springer Berlin Heidelberg, 2005, pp. 86-102.

38 M. V. Corazza, U. Guida, A. Musso, and M. Tozzi, A new generation of buses to support more sustainable urban transport policies: A path towards 'greener' awareness among bus stakeholders in Europe, Res. Transp. Econ., vol. 55, pp. 20-29, 2016.

39 E. Communities, Sustainable Urban Transport Plans: Preparatory Document in relation to the follow-up of the Thematic Strategy on the Urban Environment, 2007.

40 H. Ieda, Financial and Institutional Measures for Sustainable Urban Transport, in Sustainable Urban Transport in an Asian Context, H. Ieda, Ed. Tokyo: Springer Japan, 2010, pp. 379-415.

41 Y. Hayashi, X. Mai, and H. Kato, The Role of Rail Transport for Sustainable Urban Transport, in Transport Moving to Climate Intelligence: New Chances for Controlling Climate Impacts of Transport after the Economic Crisis, W. Rothengatter, Y. Hayashi, and W. Schade, Eds. New York, NY: Springer New York, 2011, pp. 161174.

42 P. R. Kanof, Sustainable urban transportation: An Overview, Bangkok, 2012.

43 N. Bader, Tools for Sustainable Urban Transport Experts, 2014, pp. 143.

44 C. De Stasio, D. Fiorello, F. Fermi, A. Martino, G. Hitchcock, and S Kollamthodi, On-line Tool for the Assessment of Sustainable Urban Transport Policies, Transportation Research Procedia, 2016, vol. 14, pp. 3189-3198.

45 M. Zuidgeest, M. Brussel, and M. van Maarseveen, GIS for Sustainable Urban Transport, ISPRS Int. J. Geo-Information, vol. 4, no. 4, pp. 2583-2585, 2015

46 U. Reiter, "Quantitative Methods in Sustainable Urban Transport," 2013.

47 P. N. Lee, Sustainable Urban Transport in Kuala Lumpur: A Backasting Scenario Approach, Ph.D. Thesis, Univesity College London, 2005.

48 T. V. F. Tavares, Sustainable Urban Transport: The Issue of Equity in The Emerging BRIC Countries, Ph.D. Thesis, the Graduate School of Clemson University, 2010.

49 A. Kersys, Sustainable Urban Transport System Development Reducing Traffic Congestions Costs, Inz. Ekon. Econ., vol. 22, no. 1, pp. 5-13, 2011.

$50 \mathrm{H}$. Haghshenas and M. Vaziri, Urban sustainable transportation indicators for global comparison, Ecol. Indic., vol. 15, no. 1, pp. 115$121,2012$. 
51 R. Klementschitz, R. Hössinger, and O. Roider, Results of the Implementation Process Evaluation of CIVITAS II Funded Measures for Sustainable Urban Transport, Procedia - Soc. Behav. Sci., vol. 48, pp. 64-74, 2012.

52 L. Persia, E. Cipriani, V. Sgarra, and E. Meta, Strategies and Measures for Sustainable Urban Transport Systems, Transp. Res. Procedia, vol. 14, pp. 955-964, 2016.

53 M. H. P. Zuidgeest, Sustainable Urban Transport Development: a dynamic optimisation approach, Ph.D. Thesis, University of Twente, 2005.

54 K. Cheba and S. Saniuk, Sustainable Urban Transport - The Concept of Measurement in the Field of City Logistics, Transp. Res. Procedia, vol. 16, no. March, pp. 35-45, 2016.

55 J. Kunchornrat, R. Pairintra, and P. Namprakai, Sustainable energy management in urban transport: The public's response of road congestion pricing in Thailand, Renewable and Sustainable Energy Reviews, vol. 12, no. 8. pp. 2211-2226, 2008.

56 M. E. Lindholm and M. Blinge, Assessing knowledge and awareness of the sustainable urban freight transport among Swedish local authority policy planners, Transp. Policy, vol. 32, pp. 124-131, 2014.

57 R. N. Colvile et al., Sustainable development of urban transport systems and human exposure to air pollution, Sci. Total Environ., vol. 334-335, pp. 481-487, 2004.

58 A. D. May, M. Page, and A. Hull, Developing a set of decision-support tools for sustainable urban transport in the UK, Transp. Policy, vol. 15 , no. 6, pp. 328-340, 2008.

59 A. May and S. Ison, Decision-support for sustainable urban transport strategies, Transp. Policy, vol. 15, no. 6, pp. 325-327, 2008
60 J. C. Y. Lau, Sustainable urban transport planning and the commuting patterns of poor workers in a historic inner city in Guangzhou, China, Habitat Int., vol. 39, pp. 119-127, 2013.

61 R. Joumard and J.-P. Nicolas, Transport project assessment methodology within the framework of sustainable development, Ecol. Indic., vol. 10, no. 2, pp. 136-142, 2010.

62 T. Ramani, J. Zietsman, W. Eisele, and D. Rosa, Developing Sustainable Transportation Performance Measures for TxDOT's Strategic Plan: Technical Report, Security, vol. 7, no. 2, 2009.

63 D. Bongardt, D. Schmid, C. Huizenga, and T. Litman, Sustainable Transport Evaluation: Developing Practical Tools for Evaluation in the Context of the CSD Process, Comm. Sustain. Dev. .Nineteenth Sess., no. 10, p. 44, 2011.

64 T. Litman and D. Burwell, Issues in sustainable transportation, Int. J. Glob. Environ. Issues, vol. 6, no. 4, pp. 331-347, 2006.

65 T. Litman, Transportation Indicators For Sustainability, Vancouver, 2015.

66 H. M. Alshuwaikhat and Y. A. Aina, GIS-based urban sustainability assessment: The case of Dammam city, Saudi Arabia, Local Environ., vol. 11, no. October, pp. 141-161, 2006.

67 J. A. Black, ; A Paez, and P. A. Suthanaya, Sustainable Urban Transportation: Performance Indicators and Some Analytical Approaches, J. Urban Plan. Dev., vol. 128, no. 4, pp. 733-94534, 2002.

68 A. Fujiwara and J. Zhang, Sustainable Transport Studies in Asia Hiroshima, Japan: Springer, 2013.

69 C. F. Pardo, Sustainable Urban Transport, in Shanghai Manual: A Guide for Sustainable Urban Development in the 21st Century, 2010, p. 38 . 